\title{
FACTORS AFFECTING PHYSICAL SELF-CARE AMONG PATIENTS WITH TUBERCULOSIS
}

\author{
Meidiana Dwidiyanti, Sri Padma Sari, Diyan Yuli Wijayanti
}

Lecturer of Nursing Department, Faculty of Medicine, Diponegoro University, Semarang

\begin{abstract}
Physical self-care is necessary to encourage patient involvement in health care in order to improve health outcomes among tuberculosis patients. However, factors relating to support of physical self-care among tuberculosis patients who are under treatment has very rarely been considered. This study aimed to identify the correlation between the coping strategy, the self-care management process and family well-being as factors associated with physical self-care. This is a correlation study was conducted among forty-five tuberculosis patients using purposive sampling. Data were collected in a follow up session after implementing a self-management support intervention using a physical self-care, coping strategy, self-care management process and family well-being questionnaire. The Pearson test was used to analyze the data. There was a significant association between self-care management process $(r=0.590 ; p=0.000)$, family well-being (children) $(r=0.331 ; p=0.000)$ and physical self-care. However, there was no relationship between family well-being (parent) $(p=0.789)$, coping strategy $(p=0.874)$ and physical self-care among tuberculosis patients. Self-care management process and family well-being (children) are essential factors to improve physical self-care among tuberculosis patients. Therefore, an intervention which integrates those factors are important to enhance physical self-care among patients with tuberculosis
\end{abstract}

Key word: Coping strategy; family well-being; physical self-care; self-care management process

\begin{abstract}
ABSTRAK
Physical self-care sangat diperlukan untuk meningkatkan keterlibatan pasien dalam meningkatkan kesehatan pada pasien tuberculosis. Akan tetapi, faktor-faktor terkait dengan keberhasilan pelaksanaan physical self-care pada pasien tuberkulosis yang menjalani pengobatan sangatlah jarang diperhatikan. Penelitian ini bertujuan untuk mengidentifikasi korelasi strategi koping, proses manajemen self-care dan kesejahteraan keluarga sebagai faktor-faktor yang berhubungan dengan physical self-care. Desain korelasi digunakan pada 45 pasien tuberculosis. Data diambil menggunakan teknik purposive selama sesi follow-up setelah pelaksanaan intervensi dukungan manajemen diri dengan kuesioner physical self-care, strategi koping dan proses manajemen self-care. Uji statistik Pearson digunakan untuk menganalisa data yang dikumpulkan. Hasilnya terdapat hubungan yang signifikan antara proses manajemen self-care $(r=0.590 ; p=0.000)$, kesejahteraan keluarga (anak) $(r=0.331 ; p=0.000)$ dengan physical self-care. Sementara, kesejahteraan keluarga (orang tua) $(p=0.789)$ dan strategi koping $(p=0.874)$ tidak memiliki hubungan dengan physical self-care pada pasien tuberkulosis. Proses manajemen perawatan diri dan kesejahteraan keluarga adalah faktor penting untuk meningkatkan perawatan diri fisik di antara pasien TB. Oleh karena itu, intervensi yang mengintegrasikan strategi koping dan kesejahteraan keluarga (anak) penting dalam meningkatkan physical self-care pada pasien tuberculosis.
\end{abstract}

Kata Kunci: Strategi koping, kesejahteraan keluarga, physical self-care, proses manajemen self-care 


\section{BACKGROUND}

Tuberculosis is one of the most infectious diseases leading to a high mortality rate on a worldwide scale (WHO, 2017). Globally, in 2017, 10.0 million people had tuberculosis disease; 5.8 million men, 3.2 million women and 1.0 million children (WHO, 2017). Indonesia has become the top 3rd country after India and China in the WHO's list of the 30 highest TB infected countries with $8 \%$ of the population suffering from tuberculosis disease (World Health Organization [WHO], 2018). Moreover, approximately 558.000 people have experienced drug resistance (specifically resistance to rifampicin the most effective first line drug) and $82 \%$ of them were multidrug-resistant (WHO, 2018). In 2017, the incidence of drug resistance was announced as a crisis in Indonesia where it was estimated at about 32.000 people or $12 / 100.000$ population (WHO, 2018).

Several studies have revealed that patient characteristics such as being previously treated with anti-TB drugs, living in a rural setting, being a smoker, being an alcoholic, chewing tobacco, having a body mass index below the normal range, and having a low socioeconomic status are the most common causes of MDR-TB (Shah, Shag, \& Dave, 2018; Desissa, Workineh, \& Beyene, 2018). The previous study by Stosic, et al. (2018) showed that the development of MDR-TB has also been influenced by the monthly income of the family, having poor confidence, defaulting from treatment, the stigma associated with $T B$, having a subjective feeling of sadness, the use of sedatives, and chronic obstructive pulmonary disease. So that requires intervention with a comprehensive approach, physical, mental, social and economic in providing treatment programs for patients with MDRTB.

Furthermore, the emergence of MDR-TB might be as a result of nonadherence to anti tuberculosis treatment (Charles, 2005; Tola, Tol, Shojaeizadeh \& Garmaroudi, 2015; Wurie, Cooper, Horne, \& Havyward, 2018). A study explained that the treatment adherence of tuberculosis patients itself is related to patients knowledge, attitude, health education and medication time (Ningsih, 2016). The success rate of TB treatment in Indonesia was approximately 52\% in 2017 (WHO, 2018). Thus this rate indicates that the clinical care and treatment in the tuberculosis program were considered poor and it therefore lead to treatment failure. A failed treatment plan contributes to a higher morbidity and mortality rate for tuberculosis patients (Wurie, Cooper, Horne, \& Hayward, 2018).

The adverse effects of pulmonary TB may include physical, social, economic, and psychological impacts (Dwidiyanti \& Suryawati, 2017) The physical effects can be in the form of coughing up blood, shortness of breath, sweating at night without physical activity, fever, pallor e, chest pain, and weakness (Dwidiyanti \& Suryawati, 2017). Socially, pulmonary TB also causes the patients to lack confidence because they are excommunicated and experience a bad stigma from the community (Kemenkes RI, 2011). It is estimated that $20-30 \%$ of the income of pulmonary TB patients is lost because $75 \%$ of patients are in the productive age group, i.e., 15-50 years old (Kemenkes Rl, 2011). Furthermore, pulmonary TB disease also has an impact on the patients' psychology, such as experiencing emotional problems, as well as coping strategies and family support (Venkatrajul, 2013).

The inadequate treatment outcome among tuberculosis patients has been affected by health systems, socio cultural and patient-related barriers (Oladimeji, Tsoka-Gwegweni, \& Udoh, 2017). Patients are mostly dealing with complex issues such as difficult and inequitable access to health services and having the opportunity to interact with the health workers (WHO, 2007; Oladimeji, Tsoka-Gwegweni, \& Udoh, 2017). In the 1990s, the hindrances might have been caused by the health reform, which intended to give less attention to community involvement in the development of the health system, focusing more on technical, managerial and economic sectors (WHO, 2008). Lately, policy-makers, health workers and care providers have increasingly shown an 
interest in patient empowerment and involvement in order to manage and control their disease (WHO, 2007). Patient participation has allowed them to take more responsibility for their heath, to comply with the treatment, and ensure patient centered care (WHO, 2007). Effective patient involvement also gains positive results in improving treatment outcomes and developing the awareness of patients about their health (WHO, 2008).

Coping strategies are used by the patients to resolve the stress they experience due to the illness (Jones, 2003). The coping strategies can be positive or negative and will affect the mental health aspects of patients with chronic diseases, influencing their ability to perform physical, mental and social selfcare (Jones, 2003). Thus, the researchers are interested in finding out whether coping strategies have an effect on physical self-care.

Self-care strategies are defined as the self-care behaviors that patients adopt to manage symptoms (Doran, 2011). Inherent in this definition is the patient's self-belief in their ability to choose strategies to manage their symptoms (Doran, 2011). Educational selfmanagement programs have demonstrated some effects which can have a favorable influence on behavior $d$ to smoking, alcohol consumption, nutrition and weight control, and breast selfexamination in the general population (Doran, 2011). The effects include a moderate positive effect on self-care behaviors in patients with various conditions, a strong positive effect on medication compliance in patients with hypertension, a strong positive effect on adherence to treatment, use of PRN medications, and psychomotor skills related to the use of inhaler in adults with asthma, enhanced appropriate use of medications, and increased knowledge and self-efficacy related to self-care behaviors in patients with COPD (Chronic Obstructive Pulmonary Disease) (Doran, 2011). Strategies of self-care can be both negative and positive effect. The effect of management of a symptom should include overall improvement in health status, the ability to undertake activities related to daily living, and resumption of a normal social life (Fitzpatrick, 2016).

Self-care is the most dominant and universal form of primary care and it is an important process where by a person manages his behavior or life style, including disease prevention, detection and treatment within the health care system (Bhuyan, 2004). Studies have revealed that individuals and families have the biggest role in caring for the patients with the illness (Committee on Family Caregiving for Older Adults, et al. 2016). It revealed that patient self care is highly necessary in order to achieve better health outcomes. Three main components of selfcare are emotional self-care, spiritual selfcare and physical self-care (Utah State University, 2018). In this case, developing adequate treatment among tuberculosis patients should start with physical selfcare. Physical self-care is defined as activities that improve individual physical health, including diet management and exercise and it also includes taking a medicine (Utah State University, 2018). Therefore, physical self-care is very important for patients.

Holistic health services should involve the families especially for patients with chronic diseases (Umah, 2017). It is, therefore, important to pay attention to family welfare in order to enable patients to perform self-care independently. TB patients need to have prolonged treatment and therefore they need the ability to care for themselves, and improve their skills during the healing process (Doran, 2011). It is necessary to have a management process in place in order to make the patients become more independent, especially related to improving their confidence, their awareness of the nature of the disease and their decision making ability so that the patients are to be able to care for independently and holistically (Dwidiyanti, Wiguna, \& Hasanah, 2018).

The ability of patients to perform independent self-care can be an indicator of the success of TB treatment (Venkatrajul, 2013). The previous research shows that the independent practice of physical self-care is important to improve the quality of life of patients (Umah, 2017). 
However, there are pulmonary TB patients who are unable to cope with physical complaints and feel ashamed of the disease they have. Therefore, this study aims to identify the correlation between coping strategies, the self-care management process and family wellbeing both for parents and children as factors associated with physical self-care.

\section{METHODS \\ Research Design}

This study was designed as a correlation study with a cross-sectional approach.

\section{Sample and Setting}

Participants were all tuberculosis patients, enlisted from a medical center located in Lamongan, East Java, Indonesia. This data was collected during a follow up session after a 4 weeks intervention about selft-care management. Four time' activities were to give knowledge and improve skills on how to take care of the physical aspects of care such as taking medicine, having a diet program, how to get enough sleep and doing exercise. A purposive sampling technique was used to recruit the samples. The inclusion criteria were adult patients with pulmonary TB, who did not have other diseases such as HIV, DM, and Hepatitis, and were willing to be respondents. The exclusion criteria were adult patients with incomplete data in the pulmonary health center. 45 people who fulfilled both the inclusion and exclusion criteria were sampled in this study.

\section{Research Instrument and Data Collection}

Data were collected immediately after the informed consent was received. Informed consent was given after an explanation of the purpose of the research, the benefits of the research and the confidentiality of the respondent's data. The questionnaires were distributed directly to the patients with some instructions explained clearly.

A self-administered questionnaire was used to measure the data. Sociodemographic information of participants was collected. Physical self- care questionnaire, coping strategy questionnaire, (SCMP-G) and Family wellbeing assessment tool.

To measure physical self-care, this study used a questionnaire developed by Umah (2017) with cronbach alfa $=0.78$. This questionnaire consisted of 9 question items with dichotomous answers (yes $=1$; no $=0)$. Then, the level of physical selfcare was categorized into three levels, as follows: independent (scores 0-3), starting to be independent (scores 4-6), and dependent (scores 7-9).

The coping strategy questionnaire had 42 items with cronbach alfa $=0.888$ and with a likert scale of never, sometimes, often, or always and divided into levels: good ( $\geq 85)$, moderate (43-84) and poor $(\leq 42)$ (Folkman \& Lazarus, 1988).

Self-care management processguarding (SCMP-G) had 20 items with cronbach alfa $=0.724)$. This variable was divided into 3 levels good $(\geq 131)$, moderate (104-130) and poor ( $\leq 103)$ (Jones, 2003).

Then, the family well-being assessment tool parent had 42 items, cronbach alfa $=0.943$ with levels: good $(\geq 194)$, moderate (133-193), and poor $(\leq 132)$ and the children section had 33 items, cronbach alfa $=0.916$ with levels: good ( $\geq 152)$, moderate (106-151), and poor ( $\leq 105)$ (Caldwell, 1988). Both SCMP$G$ and the family well-being questionnaire used a likert scale which was sub-scaled into strongly agree, agree, neutral, disagree and strongly disagree.

\section{Data Analysis}

The data was analyzed by using the Statistical Package for Social Sciences (SPSS) version 16. Demographic data, level of physical self-care, level of coping strategies, the self-care management process, as well as the level of family wellbeing, were measured using categories (presentation) and numerical measurements (mean SD). The Pearson correlation test was used to determine the relationship between the level of independence and coping strategies, the level of independence and patients' independence process, and the level of independence and welfare (parents and 
children) with a significant value of $p$ of $<0.05$.

\section{Ethical Consideration}

The study had been ethically approved by the research ethical commission with ethical clearance number 601/EC/FK-RSDK/2016. As a guarantee, the researcher who delivered the information related to the study to the respondent, explained about the confidentiality and anonymity of the study and asked the participants to sign the research informed consent form.

\section{RESULTS}

\section{Demographic Characteristics}

Table 1 presented the details of the demographic characteristics of participants. The majority of respondents were $(64.4 \%)$ male and $(95.6 \%)$ married. On average, participants had 3 children $(S D \pm 1.2)$ and the mean age of participants was about 39.8 years $(S D \pm 14.2)$

Table 1. Demographic characteristic of tuberculosis patients $(n=45)$

\begin{tabular}{ll}
\hline Demographic Characteristics & $\mathbf{n}(\%)$ \\
\hline Gender & \\
Male & $29(64.4)$ \\
Female & $16(35.6)$ \\
Marriage Status & \\
Single & $0(0)$ \\
Married & $43(95.6)$ \\
Divorced & $2(4.4)$ \\
The number of children, mean $(S D)$ & $3(1.2)$ \\
Age (year), mean $(S D)$ & $39.8(14.2)$ \\
\hline
\end{tabular}

\section{Physical Self-care}

Physical self-care amongst tuberculosis patients was found in the majority of respondents to be at the beginning to be independent level (55.6\%) as summarized in Table 2. Almost thirty $(28.9 \%)$ participants were independent, whereas a quarter (15.5\%) of respondents were classed as being dependent.

\begin{tabular}{lll}
\multicolumn{1}{c}{ Table 2. Physical } & \multicolumn{1}{c}{$\begin{array}{c}\text { self-care } \\
\text { tuberculosis patients }(\mathbf{n}=\mathbf{4 5})\end{array}$} \\
\hline \begin{tabular}{lll} 
Physical self-care level & $\mathbf{n}(\%)$ & Mean (SD) \\
\hline Independent & $13(28.9)$ & 50,84 \\
Begin to be independent & $25(55.6)$ & Upper 58 \\
Dependent & $7(15.5)$ & Lower 43 \\
\hline
\end{tabular}
\end{tabular}

\section{Self-care Agency of Physical Self-care}

The findings relating to the selfcare agency of physical care detailed in Table 3 Showed that overall participants had a moderate level of self-care agency. Specifically, almost two-eighths (62.2\%) of participants had a moderate coping strategy ( $M=98.33 S D \pm 7.12)$. The self-care management process, for around half of participants, was found to be moderate $(M=116.33 \quad S D \pm 5.31)$. Family well-being was at a moderate level both among parents $(66.7 \%)$ and children (55.6\%). A poor level of family well-being was only experienced by $11.1 \%$ of parents and $22.2 \%$ of children. The mean family wellbeing of parents and children was 143.22 $(S D \pm 5.35)$ and $118(S D \pm 6.96)$.

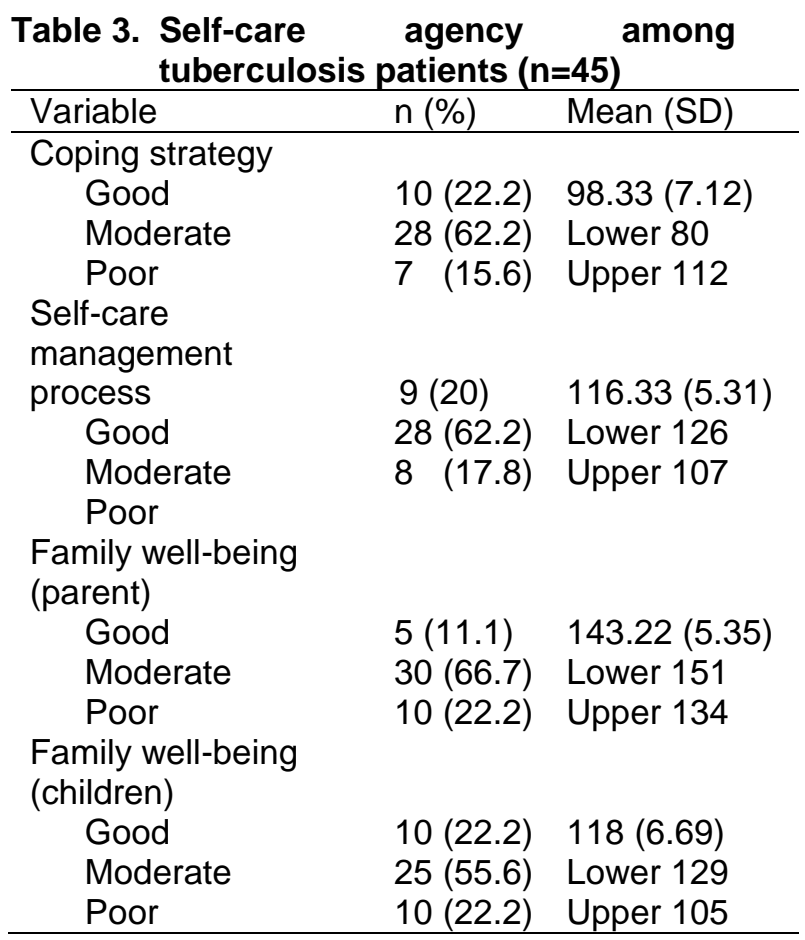

\section{The Relationship Between Self-care} Agency and Physical Self-care Among Tuberculosis Patients

The correlation between self-care agency and physical self-care among tuberculosis patients was summarized in Table 4. Self-care management process $(p=0.000)$ and family well-being (children) $(p=0.000)$ significantly correlated with physical self-care with a p-value of $<0.05$. Meanwhile, the coping strategy did not correlate with physical self-care with the $p$ value of $0.874(p>0.05)$. As well as this, there was no correlation between family 
well-being (parent) and physical self-care $(p=0.789)$.

\begin{tabular}{lcc}
$\begin{array}{l}\text { Table 4. Relationship } \\
\text { agency and } \begin{array}{c}\text { between } \\
\text { amongsical } \\
\text { (n=45) }\end{array}\end{array}$ & $\begin{array}{c}\text { self-care } \\
\text { self-care } \\
\text { patients }\end{array}$ \\
\hline Variable & $\mathrm{R}$ & $\mathrm{p}$ value \\
\hline Coping strategy & 0.031 & 0.874 \\
Self-care management process & 0.590 & 0.000 \\
Family well-being (parent) & 0.155 & 0.789 \\
Family well-being (children) & 0.331 & 0.000 \\
\hline
\end{tabular}

\section{DISCUSSION}

This study established that the self-care management process and family well-being (children) are associated with physical self-care. The patients necessarily become involved in every treatment program independently. The successfulness of physical self-care certainly involves several factors. Orem in her theory (Alligood, 2014) divided selfcare into four components which have a direct influence including: self-care agency, self-care demand, nursing agency and self-care deficit. Self-care agency has been defined as the ability of the individual to care for themselves. A previous study explained that self- care agency was directly related to self-care where physical self-care was one of several components in self-care (Suhardingsih, Mahfoed, Hargono, \& Nursalam, 2012). Self-care agency has several domains, namely cognitive skills, physical domains, emotional domains and behavioral domains that are important for overall selfcare skills (Doran, 2011).

This research shows that there is a correlation between the self-care management process and physical selfcare. This study is similar to a previous study by Kapun, Sustersic, \& Rajkovic (2016) which explained that the self-care process has a positive impact on the functionality and satisfaction of patients. The self-care process helps tuberculosis patients to be aware of physical self-care which is where the individual takes action in the areas of disease detection, prevention and treatment on their own behalf (Levin, 1976). The process of selfcare develops patients' self-love, compassion, their willingness to create a healing environment, and to learn to create constructive behaviors and attitude (American Holistic Nurses Association [AHNA], 2019). The self-care management process can identify perceived vulnerability, perceived controllability, selfabsorption and a patient's sense of obligation (Strickland and Dilorio, 2003). So when patients have a high perceived vulnerability, a high perceived controllability, high self-absorption and a high sense of obligation, this makes the patient more aware of the importance of physical safe-care. The self-care management process is very influential on the physical self-care of TB patients. To perform self-care management, patient's needs to have the self-efficacy to care for themselves. Therefore, when the selfefficacy increases, the patients' ability to be physically independent also increases (Noorratri, Margawati \& Dwidiyanti, 2017). The patient requires not only physical but also emotional independence, which affects their health as a whole (Namuwali, Mendrofa, \& Dwidiyanti, 2016).

Family well-being (children) was found to be associated with physical selfcare. Most of the tuberculosis patients had 3 children. This study is simillar to a previous study conducted by Nakaoka et al. (2006) which revealed that $74 \%(53 / 72)$ of children who participated in the study had maintained contact with their parents who were smear-positive TB. This could make the patients worry about their family well-being (children). WHO (2017) explained that tuberculosis patients with children under 5 years old have a high risk of transmitting tuberculosis virus/bacteria. This will affect patient's moves toward physical self-care due to fear of transmitting the disease.

Family well-being is one of the factors related to physical self-care. This study found that family well-being (parent) did not correlate to physical self-care. This can be affected by several factors such as parent's existence, age, and marital status (Alligood, 2014). The physical self-care of patient's with parents who have died might not be affected. The fact that the average age of patients was 39.8 years showed that most of them were married and their spouses supporting them to do physical self-care. Married patients were 
considered more likely to be successful with the tuberculosis treatment due to the fact that the patients have their spouses as supporters (Ali, Karanja, \& Karama, 2017; Sengul, et al., 2015).

In other research, good support and care was considered as receiving the necessary attention and help in the daily routine, monetary help, emotional and moral support and motivation for early recovery (Namuwali, Mendrofa, \& Dwidiyanti, 2016). The family provided support by accompanying the patient to the health centre, reminding them about medicines, and providing meals (Nagarkar, 2012). There is a positive relationship between family support and self-care behavior. When the respondent had received a high level of family support, they had initiated an adequate level of self-care behavior. These three aspects of support, combined with other supportive dimensions, such as intimacy support and moral support, may help family members develop a sense of security during stressful situations and provide them with opportunities to express their feelings and concerns, which can be beneficial for psychological self-care. All these supportive dimensions contribute to family members' feelings of being loved, cared for and valued; which can increase their hope, self confidence and self-esteem; increase their self-care knowledge and strengthen their self-care ability (Xiaolian, 2002).

The findings revealed that the coping strategy did not correlate to physical self-care. However, there is limited research on how the coping strategy can affect physical self-care significantly. Suhardingsih, Mahfoed, Hargono, \& Nursalam (2012) showed that the coping strategy did not directly correlate to physical self-care. The coping strategy may correlate to physical selfcare when there is a combination of professional encouragement and personal growth (Zaccari, 2017). However the coping strategy was affected by confounding factors of self-care such as age, gender, marital status, and support (Alligood, 2014)

This study is in contrast with the result of the study by Sukartini (2017) which showed that a proactive coping strategy had a positive correlation with self-care management in patients with pulmonary tuberculosis. In Sukartini's study, the overall self-care management was assessed. Meanwhile, the present study only investigated the effect of coping strategies on physical self-care. The patients need to be mentally independent in order to be able to improve positive coping. Individuals who use proactive coping will take actions to solve the challenge by identifying and using the necessary resources (Sukartini, 2017). Positive coping strategies require mental independence; however, this study only measured physical independence, which was not affected by the coping strategies.

Sousa (2002) explained that self-care agency has 3 components; 1 ) foundational 2) enabling and 3) operational. Operational factors are related to an individual's ability to perform self-care actions (Carter, 1998). Self-care operations are the following a personal skill to recognize and their environment (family well-being); making judgments and decisions (coping strategy); and nursing care implementation (self-care management process) (Gast, et al., 1989; Sousa, 2002). The ability of self-care is beneficial for individual patients and the health care system (Doran, 2011). It is because self-care will increase patient's responsibility, control and autonomy (Dwidiyanti \& Suryawati, 2017). Self-care is needed for patients with chronic conditions with a lengthy healing process (Doran, 2011). Physical self-care is defined as an activity that enhances an individual's physical health, including their diet, exercise, and medication (Lawn \& Schoo, 2010) Patients with chronic conditions and lengthy treatment such as tuberculosis need the practice of physical self-care (Lawn \& Schoo, 2010). This study investigated the relationship between physical self-care, coping strategies, and the process of self-care management of family wellbeing (parents) and family well-being (children).

This study focused on exploring operational factors; coping strategies, selfcare management process and family well-being as factors affecting the 
accomplishment of physical self-care (Figure 1).

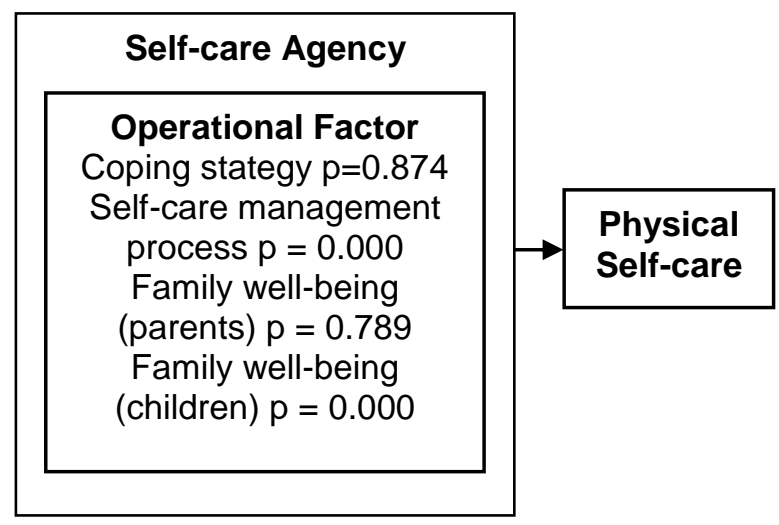

Figure 1.Factors related to physical selfcare

Some limitations in this research were acknowledged. This study was conducted in only one setting in Indonesia. The variable in self-care agency only focused on limited foundational and operational factors. Further research may broaden the research setting, increase the sample size and explore other factors of physical self-care.

The implications in this study can provide an evidence base for family and health workers in caring for TB patients and optimize the health status of TB patients and families. Self-care management intervention requires comprehensive actions, namely physical, mental, social and spiritual independence.

\section{CONCLUSION}

Self-care management process and family well-being (children) are correlated with physical self-care among tuberculosis patients whereas coping strategies and family well-being (parent) did not correlate with physical self-care for tuberculosis patients.

Therefore, health workers in professional health care should pay attention to factors influencing the physical self-care of the patients by helping and encouraging patients to improve, strengthen, and develop better self-care agency. An adequate intervention program with some interventions which include coping strategies and family well-being (children) is important to be continuously delivered to patients in order to optimize the self-care of patients with TB especially physical self-care. It is necessary to measure the level of independence as a whole, not only the physical, but also the level of mental, social and cultural independence.

\section{ACKNOWLEDGEMENT}

The authors would like to show gratitude to the health care providers for their permission to conduct the research and to Diponegoro University who have funded this research. The authors would also like to thank all colleagues, nurses and students who have given their support to this study.

\section{CONFLICT OF INTEREST}

None

\section{REFERENCES}

AHNA (American Holistic Nurses Association). (2019). Holistic SelfCare for Nurses. Topeka. Retrieved From: Https://Www.Ahna.Org/Mem bership/Member-Advantage/Whatis self-Care

Ali, M. K., Karanja, S., \& Karama, M. (2017). Factors Associated with Tuberculosis Treatment Outcomes Among Tuberculosis Patients Attending Tuberculosis Treatment Centres in 2016-2017 in Mogadishu, Somalia. The Pan African Medical Journal, 28, 197.

Alligood, M. R. (2014). Nursing Theory \& Their Work (8 Th Ed). The CV Mosby Company St. Louis. Toronto. Missouri: Mosby Elsevier. Inc

Bhuyan, K. K. (2004). Health Promotion through Self-Care and Community Participation: Elements of a Proposed Programme in the Developing Countries. BMC Public Health, 4 (11).

Carter, P. A. (1998). Self-Care Agency: The Concept and How It Is Measured. Journal of Nursing Measurement. 6(2), 195-207. 
Caldwell, S. K. (1988). Measuring Family Well-Being: Conceptual Model, Reliability, Validity, and Use. In C. F. Waltz \& O.L. Strickland (Eds.), Measurement of Nursing Outcome: Vol. 1: Measuring Client Outcome (287-308). New York: Springer Publishing Co.)

Charles, P. (2005). Felton National Tuberculosis Center. Adherence to Treatment for Latent Tuberculosis Infection. A Manual for Health Care Providers.

Desissa, F., Workineh, T., \& Beyene, T. (2018). Risk Factors for the Occurrence of Multidrug-Resistant Tuberculosis among Patients Undergoing Multidrug-Resistant Tuberculosis Treatment in East Shoa, Ethiopia. BMC Public Health. 18:422

Doran, D.M. (2011). Nursing Outcomes: The State of the Science. Canada:Jone \& Bartlett Learning.

Dwidiyanti, M. Wiguna, R.I., Ningsih, H.E.W, 2018. Mindfulness Untuk Self-Care. Semarang: Undippress. ISBN 978-979-097-553-8

Dwidiyanti, M., \& Suryawati, C. (2017). Correlation Between Self-Reliance Of Its Patients And Their Medication Adherence In Magelang Pulmonary Health Center, Indonesia. Advanced Science Letters, 23(4), 3302-3305

Folkman, S., \& Lazarus, R. (1988). Manual for the Ways of Coping Questionnaire. Palo Alto, CA: Consulting Psychologists Press

Fitzpatrick, J.J., \& Mccarthy, G. (2016). Nursing Concept Analysis Applications to Research and Practice. New York:Springer Publishing Company.

Gast, H., Denyes, M., Campbell, J., Hartweg, D., Schott-Baer, D., \& Isenberg, M. (1989). Self-care agency: Conceptualizations and operationalizations. Advances in Nursing Science. 12(1), 26-38

Jones, L. C. (2003). Measuring Guarding As a Self-Care Management Process in Chronic Illness: The SCMP-G.

Strickland, O.L., Dilorio, C. (2003) Measurement Nursing Outcomes Second Edition. New York: Springerlink

Kapun, M. M., Sustersic, O., \& Rajkovic, V. (2016). The Integrated Patient's Self-Care Process Model. Nursing Informatics.108-112

Kemenkes RI, (2011). Pedoman Nasional Pengendalian Tuberkulosis. Kementrian Kesehatan Republik Indonesia Direktorat Jenderal Pengendalian Penyakit Dan Penyehatan Lingkungan.

Lawn, S. And Schoo, A. (2010) Supporting Self-Management of Chronic Health Conditions: Common Approaches. Journal of Patient Education and Counseling 80:205-2011

Levin, L. S. (1976). The Layperson as the Primary Health Care Practitioner, Public Health Report, 91 .206-10.

Nagakar, A.K., Dhake, D., \& Jha, P. (2012) Perspective of Tuberculosis Patients on Family Support and Care in Rural Maharashtra. Indian Journal of Tuberculosis

Nakaoka, H., Lawson, L., Squire, S. B., Coulter, B., Ravn, P., Brock, I., Hart, C. A., Cuevas, L. E. (2006). Risk for Tuberculosis among Children. Emerging Infectious Diseases, 12(9), 1383-8.

Namuwali, D., Mendrofa, F. A., \& Dwidiyanti, M. (2016). Deep Breathing Relaxation Techniques Improve Emotional Control On Tuberculosis Patients. International Journal of Public Health Science (IJPHS), 5(3), 325-328. 
Ningsih, H. E. W. (2016). Faktor-Faktor Yang Berhubungan Dengan Kepatuhan Berobat Pada Pasien TB Paru Di Wilayah Kerja Puskesmas Semuntul Kabupaten Banyuasin Sumatera Selatan. Skripsi. Universitas Airlangga

Noorratri, E. D., Margawati, A., \& Dwidiyanti, M. (2017). Improving Self-Efficacy and Physical SelfReliance of Patients with Pulmonary Tuberculosis through Mindfulness. Nurse Media Journal of Nursing, 6(2), 81-90.

Oladomeji, O., Tsoka-Gwegweni, J., \& Udoh, E. E. (2017). Barriers and Strategies to Improve Tuberculosis Care Services in ResourceConstrained Setting: A Qualitative Analysis of Opinions from Stakeholders in Oyo State South West Nigeria. SMGroup. Retrieved from: https://smjournals.com/ebooks/ tuberculosis/chapters/TB-17-18.pdf

Sengul, A., Akturk, U. A., Aydemir, Y., Kaya, N., Kocak, N. D., \& Tasolar FT. (2015). Factors Affecting Successful Treatment Outcomes in Pulmonary Tuberculosis: A SingleCenter Experience in Turkey, 20052011. The Journal of Infection in Developing Countries, 9(08), 821-8

Shah, A. M., Shag, R. B., \& Dave, P. N. (2018). Factors Contributing to the Development of Multidrug-Resistant Tuberculosis. National Journal of Physiology, Pharmacy and Pharmacology. 8(10), 1463-9

Stosic, M., Vukovic, D., Babic, D., Antonijevic, G., Foley, K. L., Vujcic, I., \& Grujicic, S. S. (2018). Risk Factors for Multidrug-Resistant Tuberculosis among Tuberculosis Patients in Serbia: A Case-Control Study. BMC Public Health. 18:1114

Sousa, V. (2002). Conceptual analysis of self-care agency. Online Brazilian Journal of Nursing, 1(3), 3-12.
Suhardingsih, S. A. V., Mahfoed, M. H., Hargono, R., \& Nursalam. (2012). The Improvement Of The Self-Care Agency For Patients With Ischemic Stroke After Applying Self-Care Regulation Model In Nursing Care. Jurnal Ners. 7(1). 13-23.

Sukartini, T., Ramadhani, \& Hidayati, L.(2017). Relationship between Proactive Coping and Self-Care Management in Patient with Pulmonary Tuberculosis. Jurnal Ners, 12(2), 233-238. Tola, H. H., Tol, A., Shojaeizadeh, D., \& Garmaroudi, G. (2015). Tuberculosis Treatment Non-Adherence and Lost to follow up among TB Patients With or Without HIV in Developing Countries: A Systematic Review. Iran J Public Health, 44(1), 1-11.

Umah, K. (2017). Pengaruh Paket Dukungan Kader Kesehatan Terhadap Keterampilan Kemandirian Fisik Pasien Tuberculosis Paru. Tesis. Universitas Diponegoro.

Utah State University. (2018). Self Help/Self-Care. Counseling and Psychological Services. Retrieved From: Https://Counseling.Usu.Edu/ Referring/Self

Venkatrajul B, Prasad S. 2013. Psychosocial Trauma of Diagnosis. A Qualitative Study on Rural TB Patients Experiences in Nalgonda District Andhira Pradesh. Indian J Tuber, 2013; 60: 162-7

World Health Organization. (2018). Global Tuberculosis Report 2018. Geneva: World Health Organization. Licence: CC BY-NC-SA 3.0 IGO. Retrieved From: Https://Www.Who.Int/Tb/Publi cations/Global_Report/En/

WHO. (2018). Indonesia National TB Program; Kemenkes RI \& Muhammadiyah. Retrieved From: Https://Www.Who.Int/Tb/Features_A rchive/Indonesia_11apr18.Pdf?Ua=1

WHO. (2017). Global Tuberculosis Report 2017. Geneva. ISBN 978-92-4- 
Jurnal Keperawatan Soedirman 14 (3) 2019 : 155 - 165

156551-6. Retrieved From: Https://Www.Who.Int/Tb/Publications /Global_Report/Maintext_13Nov201 7.Pdf

WHO. (2008). Implementing the WHO Stop TB Strategy: A Handbook for National Tuberculosis Control Programmes. Geneva: World Health Organization; 26, Involvement of communities and patients in tuberculosis care and prevention. Retrieved from: https://www.ncbi.nlm.nih.gov/books/ NBK310754/

WHO. (2007). Empowerment and involvement of tuberculosis patients in tuberculosis control: Documented experienced and interventions. France: WHO Press. Retrieved from: https://apps.who.int/iris/bitstream/ha ndle/10665/69607/WHO_HTM_STB _2007.39_eng.pdf;jsessionid $=3859 \mathrm{~B}$
15889011861475969CA678249D4? sequence $=1$

Wurie, F. B., Cooper, V., Horne, R., \& Hayward, A. C. (2018). Determinants of Non-Adherence to Treatment for Tuberculosis in High Income and Middle-Income Settings: A Systematic Review Protocol. BMJ Open 2018; 8:E019287

Xiaolian, J. Chaiwan, S., Panuthai, S. Yijuan, Lei, Y. \& Jiping L., (2002). Family Support and Self Care Behavior of Chinese Chronic Obstructive Pulmonary Disease Patients. Nursing and Health Science. (2002), 4, 41-4

Zaccari, A. (2017) Vicarious Trauma Coping and Self-Care Practices Among Trauma Therapists. Walden Dissertations and Doctoral Studies. Walden University. 